\title{
INVESTIGATION ON THE FLOW PROPERTIES AND COMPRESIBILITIES OF DIFFERENT DIRECT TABLETING AGENTS BY USING PYRIDOXINE HYDROCHLORIDE AS A MODEL DRUG
}

\author{
MODEL ETKEN MADDE OLARAK PRİDOKSİN HIDROKLORÜR \\ KULLANILARAK FARKLI DOĞRUDAN TABLETLEME AJANLARININ AKIŞ \\ ÖZELLİKLERİ VE BASILABİLİRLİK ÜZERINE ETKİSINIIN İNCELENMESİ
}
Müge KILIÇARSLAN ${ }^{1 *}$, Rüya ÇAMCA ${ }^{1}$, Selin IMAMOĞLU ${ }^{1}$, Mustafa Naim ANTEP ${ }^{1}$, Başak OCAK $^{1}$, Nilüfer YÜKSEL ${ }^{1}$

${ }^{1}$ Ankara University, Faculty of Pharmacy, Department of Pharmaceutical Technology, 06100

Tandoğan - Ankara, TURKEY

\section{ABSTRACT}

The purpose of this study was to evaluate the flow properties and compressibilities of different direct tableting agents (DTA) by using pyridoxine hydrochloride as a model drug. Avicel PH 102 ${ }^{\circledR}$, Tablettose $100^{\circledR}$, StarLac ${ }^{\circledR}$ and Ludipress ${ }^{\circledR}$ were used as DTAs. Flow rate, angle of repose, bulk and tapped densities of DTAs, binary mixture of drug and DTA and mixtures of drug-DTA-magnesium stearate were examined. Carr's index and Hausner index were calculated to determine the consolidation character of powder mixtures. Tablets were compressed at different pressure by a manual hydraulic press. Heckel and Kawakita equations were fitted to the data obtained from compressibility studies. StarLac ${ }^{\circledR}$ and Ludipress ${ }^{\circledR}$ showed good flow properties as indicated by the lowest angle of repose and the highest flow rate. The Hausner and Carr's index values of these agents were in the range of good flow characteristic values according to the pharmacopoeial limits. The lowest Py values of powder mixture prepared with StarLac ${ }^{\circledR}$ or Ludipress ${ }^{\circledR}$ were also pointed out of acceptable compressibility. When Tablettose ${ }^{\circledR}$ was used in the formulation, capping and lamination problems were occurred at the higher compression pressure. The effect of the increased percent amount of drug (12\% to 36\%) on the consolidation properties and compressibility was also determined at the 
formulations prepared with Ludipress ${ }^{\circledR}$. Optimum consolidation and compressibility characters were obtained by $18 \%$ drug while more than $24 \%$ drug amount was caused to decreased volume reduction.

Key words: Direct tableting, Heckel equation, Kawakita equation, flow property, compressibility.

\section{ÖZET}

Bu çalışmanın amacl, model etken madde olarak Pridoksin HCl kullanarak farkl doğrudan tabletleme ajanlarının (DTA) akış özellikleri ve basılabilirlik üzerine etkisinin değerlendirilmesidir. DTA olarak Avicel PH 102 ${ }^{\circledR}$, Tablettose $100^{\circledR}$, StarLac ${ }^{\circledR}$ ve Ludipress ${ }^{\circledR}$ kullantld. DTA'ların, DTA ve etken maddenin ikili karışımının ve DTA-etken madde ve magnezyum stearat karışımının akış hızı, yığın açısı, küme ve sıkıştırılmış dansitesi incelendi. Toz karışımlarının akış özelliklerini belirlemek için Carr Indeks, Hausner Indeks değerleri hesaplandı. Tabletler hidrolik el presi ile farklı basınçlarda basıldı. Basılabilirlik çalışmalarından elde edilen veriler Heckel ve Kawakita eşitliklerine uygulandl. StarLac ${ }^{\circledR}$ ve Ludipress ${ }^{\circledR}$ en düşük yığın açısı, en yüksek akış hızı ile iyi akış özellikleri gösterdi. Bu ajanların Hausner ve Carr indeks değerleri farmakope limitlerine göre iyi akış özelliği aralığındaydl. StarLac ${ }^{\circledR}$ ve Ludipress ${ }^{\circledR}$ ile hazırlanan toz karışımlarının en düşük Py değerini vermesi de bu formülasyonların basılabilirliğinin uygun olduğunu gösterdi. Formülasyonda Tablettose ${ }^{\circledR}$ kullanıldı̆̆ında yüksek basıçlarda kapak atma ve laminasyon oldu. Aynı zamanda, Ludipress ${ }^{\circledR}$ ile hazırlanan formülasyonlarda artan etken madde miktarının (\%12-\%36) akış özellikleri ve basıma etkisi de incelendi. \%24 den fazla etken madde kullanımı hacim düşüşünün azalmasına sebep olurken, \%18 etken madde ile optimum konsolidasyon ve basllabilirlik özellikleri elde edildi.

Anahtar kelimeler: Doğrudan tabletleme, Heckel eşitliği, Kawakita eşitliği, Akış özelliği, Basılabilirlik.

\section{INTRODUCTION}

Tablets are one of the most preferred dosage forms in pharmaceutical area due to easy manufacturing, dose accuracy, good patient compliance and relatively low cost (1- 6). There are several tablet manufacturing methods but the most appropriate technology for industrial production is direct compression. Direct compression involves only two production steps such as dry mixing of the excipients and compression. The simplicity and reduced production cost are the primary advantages of this method. Direct compression is preferred in terms of better stability of active ingredient, relatively faster dissolution and reduces the documentation and validation requirements, and ensures the compliance to the requirements of current good manufacturing practices due to the lesser contamination risk $(2,3,5,6)$. However, lots of pharmaceutical materials have poor compressibility properties. Therefore the choice of the excipients in direct tableting is essential regarding good flowability, low segregation potency and good compressibility properties $(2,3,6$, 7). Single-component excipients do not always provide all the ideal characteristics. Thus, 
multifunctional co-processed excipients are in request in recent years and co-processing is one of the most widely explored and commercially utilized methods for the preparation of directly compressible agents. Co-processing is based on the combinations of two or more plastic and brittle materials to provide synergistic effect in terms of compressibility by several methods such as chemical modification, physical modification, grinding and sieving, crystallisation, spray drying, granulation/agglomeration and dehydration $(2,4,6-8)$. Co-processed products are single-bodied excipients acting as filler, binder and disintegrant and improved flow properties, improved compressibility, better dilution potential, fewer fill weight variation, reduced lubricant sensitivity are some of advantages of co-processed materials $(2,4,6)$. The dilution potential is ability of the excipients to retain its compressibility even when diluted with another material. Co-processed excipients should have high dilution potential so that the final dosage form has a minimum possible weight $(4,6)$.

Avicel PH102 ${ }^{\circledR}$, Tablettose $100^{\circledR}, \operatorname{StarLac}^{\circledR}$ and Ludipress ${ }^{\circledR}$ were used as DTAs in this study due to their different structure and nature. Avicel PH 102 is one of the most important DTA structurally based on microcrystalline cellulose. It has a granular form and larger particles with better flowability and lubricity but lower compressibility than that of Avicel PH $101(3,6,9)$. Tablettose $100^{\circledR}$ is the brand name for an agglomerated alfa-lactose-monohydrate [Ph. Eur./USP/NF/JP]. It combines the flowability of coarse lactose and the good compressibilty of fine milled lactose (10). It has better binding property than alfa-lactose-monohydrate, but not as good as spray dried lactose (6). StarLac ${ }^{\circledR}$ is a spray dried blend of 85 parts lactose monohydrate [Ph. Eur./USP/NF] and 15 parts white native maize starch [Ph. Eur./USP/NF] based on dry substance. It is a one-body compound and co-processed DTA with typical spherical particles. These two components cannot be segregated by mechanical method. Good flowability depending on the spray drying process, an acceptable crushing force due to its lactose content, rapid disintegration depending on starch are some of the advantages of this DTA $(4,6,11)$. Ludipress ${ }^{\circledR}$ is also co-processed product that is a unique three in one system, combining the strengths of three excipients: $93 \%$ lactose as carrier and filler, 3.5\% Kollidon 30 as a binding agent, and 3.5\% Kollidon CL as one of the best disintegrants on the market. At low compression pressure Ludipress $^{\circledR}$ gives harder tablets and although contains disintegrant, the disintegration take more time than tablets containing Tablettose ${ }^{\circledR}$ and it is reported that binding capacity of it was higher than microcrystalline cellulose. Dilution potential of Ludipress ${ }^{\circledR}$ is differed with different drugs (4, $6,12-14)$ 
The objective of this study was to investigate of the flow properties and compressibilities of Avicel PH $102^{\circledR}$, Tablettose $100^{\circledR}$, StarLac ${ }^{\circledR}$ and Ludipress ${ }^{\circledR}$ by using pyridoxine hydrochloride (PDH) as a model drug which exhibits poor compression ability and fair flow properties.

\section{MATERIALS AND METHODS}

\section{Materials}

Pyridoxine HCL was obtained from Abbott Laboratories (Istanbul, Turkey). Avicel PH $102^{\circledR}$ (Select Chemie, FMC, Switzerland), Tablettose $100^{\circledR}$ (Meggle GmbH, Germany), StarLac ${ }^{\circledR}$ (Meggle GmbH, Germany) and Ludipress ${ }^{\circledR}$ (BASF, Germany) were used as DTAs. All other materials were of analytical grade.

\section{Methods}

\section{Preparation of powder mixtures}

All tablet formulation theoretically contained $12 \%$ drug, $88 \%$ DTA and $2 \%$ magnesium stearate of total amount of drug and DTA. Each formulation was calculated for an amount of $800 \mathrm{~g}$ as a batch size. DTAs were sifted from a sieve with apertures $0.210 \mathrm{~mm}$ and the powder under the size was used for the experiments. Drug and each DTA were mixed at $25 \mathrm{rpm}$ for $25 \mathrm{~min}$ by a cube mixer (Erweka, Munich, Germany) at room temperature. Each batch was lubricated with magnesium stearate by additional mixing at $25 \mathrm{rpm}$ for $6 \mathrm{~min}$ (Table 1).

Table 1. Composition of the formulations (all values in $\% \mathrm{w} / \mathrm{w}$ ).

\begin{tabular}{lccccccc}
\hline & F-A & F-T & F-S & FL-12 & FL-18 & FL-24 & FL-36 \\
\hline Pyridoxine HCl & 12 & 12 & 12 & 12 & 18 & 24 & 36 \\
Avicel PH102 & & & & & & \\
Tablettose $100^{\circledR}$ & 88 & - & - & - & - & - & - \\
StarLac $^{\circledR}$ & - & 88 & - & - & - & - & - \\
Ludipress $^{\circledR}$ & - & - & 88 & - & - & - & - \\
Magnesium Stearate* $^{\circledR}$ & - & - & - & 88 & 82 & 76 & 64 \\
\hline
\end{tabular}

$* \%(\mathrm{w} / \mathrm{w})$ of total amount of drug and DTA 


\section{Determination of flow rates and angle of reposes}

Flow rate and angle of repose, bulk and tapped densities were determined for drug alone, each DTA used in the formulation, binary mixture of drug-DTA, and final mixture of drug-DTAmagnesium stearate, respectively.

$25 \mathrm{~g}$ of powder was weighed and the powder flow rate was measured as the mass per time using a glass funnel with an orifice of $10 \mathrm{~mm}$ in diameter $(\mathrm{n}=3)$. Angle of repose of the powder was measured by static angle of repose method. As the same volume for each time, $50 \mathrm{~mL}$ of powder flowed through a funnel and felled free onto a surface $(n=3)$. The height $(\mathrm{h})$ and diameter (r) of the resulting cone were measured and the angle of repose $(\theta)$ calculated from the equation $(\tan \theta=h / r)(15-18)$.

\section{Determination of consolidation behaviour}

Powders were gently poured into a $10 \mathrm{~mL}$ graduated cylinder through a funnel. The weight of $10 \mathrm{ml}$ was then determined and the bulk density (BD) was calculated as the ratio of mass of an untapped powder to its volume $(\mathrm{g} / \mathrm{mL})$. The tapped densities (TD) were obtained by mechanically tapping a graduated cylinder containing powder from a height of $25 \mathrm{~mm}$. After observing the initial powder volume, the cylinder was tapped $5,25,50,75,100,125,150,175$, and 200 times until achieving constant volume, the resulting reduction in volume was recorded and then the TD was calculated from the ratio of mass of powder to constant tapped volume $(\mathrm{g} / \mathrm{mL})$. Carr's Index $(\mathrm{CI})$ and Hausner Index (HI) were calculated according to Eq. 1.and

Eq. 2. $(5,15-20)$.

$$
\begin{aligned}
& \text { Carr's Index }=100 x[(\mathrm{TD}-\mathrm{BD}) / \mathrm{TD}] \\
& \text { Hausner Index }=\mathrm{TD} / \mathrm{BD}
\end{aligned}
$$

\section{Determination of compressibility behaviour by Heckel and Kawakita equations}

The compressibility studies were performed by using $10 \mathrm{~mm}$ flat face punch and handoperated hydraulic press (Üçler, İstanbul, Turkey). The appropriate amounts of powder mixtures were pressed at 54.16, 108.31, 162.47, 216.63, 324.94, and 433.26 MPa. When the desired pressure was reached, it was kept at this value for $20 \mathrm{sec}$. The height of the compact was measured accurately and the volume was calculated $(n=4)$. The compressibility data of each formulation were evaluated by fitting to Heckel equation (Eq. 3 and 4 ) where $D$ is relative density of the tablet and $\mathrm{P}$ is the applied pressure (MPa), $\mathrm{K}$ is a constant determined from the slope and A from the intercept of a plot of $\ln (1 / 1-D)$ vs. P $(8,14,21-24)$. 


$$
\begin{gathered}
\frac{d D}{d P}=K(1-D) \\
\ln \left[\frac{1}{1-D}\right]=K P+A
\end{gathered}
$$

The data was also analyzed by Kawakita equation (Eq. 5) in which $P$ is the applied pressure $(\mathrm{MPa}), \mathrm{C}$ is the degree of volume reduction, $1 / \mathrm{ab}$ is determined from intercept and $1 / \mathrm{a}$ from the slope a plot of $P / C$ vs $P(8,14,22,23)$.

$$
\frac{P}{C}=\frac{1}{a b}+\frac{\mathrm{P}}{a}
$$

\section{RESULTS AND DISCUSSION}

\section{Determination of flow properties}

In the tablet manufacturing, powder flow in hoppers from an orifice is an important factor in order to achieve content and weight uniformity of the final dosage form $(9,15,24)$. There are many factors that can affect flow properties of a powder such as particle size and shape, cohesion between like surfaces such as particles of bulk solid or adhesion between two unlike surfaces such as particle and hopper wall. Flow problems depending on the cohesion are likely to occur by decreasing particle size under $100 \mu \mathrm{m}(9,16)$.

There are four commonly reported testing methods for the determination of the flow properties; angle of repose, compressibility index or Hausner ratio, flow rate through an orifice and shear cell (15). Except shear cell method, the others were performed in this study.

The particle size distribution of PDH has been determined by sieving method in a previous study and it has been found that $84 \%$ of the drug is smaller than $0.110 \mathrm{~mm}$ and $16 \%$ of the drug is smaller than $0.038 \mathrm{~mm}$; geometric mean size of the drug $(50 \%)$ was $0.060 \mathrm{~mm}$. PDH has fair flowability; its measured angle of repose is $38.3 \pm 1.38$ (24). Thus, the size range smaller than $0.210 \mathrm{~mm}$ of DTAs was used in the experiments in order to prevent any segregation problem and to compare different direct tableting agents excluding the particle size differences.

Angle of repose within $25^{\circ}-30^{\circ}$ generally indicates excellent flow property, while $31^{\circ}-35^{\circ}$ shows good, $36^{\circ}-40^{\circ}$ shows fair and more than $46^{\circ}$ angle of repose indicates poor flow properties 
(17). Flow rate and angle of repose of drug alone could not be determined due to the cohesion and friction between drug particles. The drug had gained flowability after adding DTA and magnesium stearate. Results of angle of repose, flow rate, CI and HI of the different DTAs, binary mixtures of DTA -PDH and mixtures of DTA-PDH- magnesium stearate were given in Table 2. Angle of repose of powder and powder mixtures ranged between $24.4^{\circ} \pm 0.418$ and $38.2^{\circ} \pm 0.039$. Due to the fair flow properties of $\mathrm{PDH}$, the flow rates were decreased while the angles of repose increased for binary mixtures compared to those of DTAs alone. Addition of the lubricant did not contribute the flow properties except for F-T (including Tablettose $100^{\circledR}$ ) and F-S (including StarLac ${ }^{\circledR}$ ). The lowest angle of repose $\left(24.4^{\circ} \pm 0.418\right)$ and the highest flow rate $(6.77 \pm 1.61 \mathrm{~g} / \mathrm{sec})$ were obtained by F-S formulation containing StarLac ${ }^{\circledR}$-PDH-magnesium stearate. As a result of spherical shape of $\operatorname{StarLac}^{\circledR}$ which is formed by spray drying of lactose monohydrate together with maize starch (11), the flow rate increased for F-S formulation (Table 2). Generally, spheres have minimum interparticulate contact and optimal flow properties (15). The lowest flow rate obtained with cellulose base DTA (Avicel PH $102^{\circledR}$ ) and F-A formulation $(1.47 \pm 1.13 \mathrm{~g} / \mathrm{sec})$.

The percentage compressibility of a powder (CI) is an indirect method of measuring powder flow from bulk densities. CI is a measure of powder bridge strength and stability, and HI is a measure of the interparticulate friction and consolidation. CI values below $10 \%$ and $\mathrm{HI}$ value below 1.11 indicates excellent flow character, whereas CI values above $38 \%$ and $\mathrm{HI}$ value more than 1.60 is considered very, very poor flow $(15,17-20)$.

Table 2. Results of flow properties and consolidation behaviour of each DTA, binary mixture of PDH-DTA, and final mixture of PDH-DTA-magnesium stearate, respectively.

\begin{tabular}{|c|c|c|c|c|}
\hline $\begin{array}{l}\text { Powder and Powder } \\
\text { Mixture }\end{array}$ & $\begin{array}{l}\text { Angle of Repose } \\
\text { (degree) } \pm \mathrm{SE}^{*}\end{array}$ & $\begin{array}{l}\text { Flow Rate } \pm \mathrm{SE}^{*} \\
(\mathrm{~g} / \mathrm{sec})\end{array}$ & $\begin{array}{l}\text { Hausner } \\
\text { Index }\end{array}$ & $\begin{array}{l}\text { Carr's } \\
\text { Index (\%) }\end{array}$ \\
\hline Avicel PH $102^{(B)}$ & $33.6 \pm 0.481$ & $2.40 \pm 0.099$ & 1.25 & 20.0 \\
\hline Avicel PH $102^{\circledR}+\mathrm{PDH}$ & $35.4 \pm 0.787$ & $2.36 \pm 0.087$ & 1.25 & 24.9 \\
\hline F-A & $38.2 \pm 0.924$ & $1.47 \pm 0.032$ & 1.25 & 20.3 \\
\hline Tablettose $100^{\circledR}$ & $29.8 \pm 0.871$ & $4.55 \pm 0.074$ & 1.29 & 22.5 \\
\hline Tablettose $100^{\circledR}+\mathrm{PDH}$ & $32.8 \pm 1.26$ & $1.97 \pm 0.197$ & 1.27 & 21.1 \\
\hline F-T & $31.7 \pm 1.10$ & $2.98 \pm 0.399$ & 1.19 & 16.2 \\
\hline $\operatorname{StarLac}^{\mathbb{B}}$ & $25.9 \pm 0.867$ & $4.42 \pm 0.029$ & 1.19 & 16.6 \\
\hline $\operatorname{StarLac}^{\circledR}+$ PDH & $27.2 \pm 0.399$ & $5.93 \pm 0.241$ & 1.19 & 12.9 \\
\hline F-S & $24.4 \pm 0.418$ & $6.77 \pm 1.31$ & 1.13 & 11.3 \\
\hline Ludipress ${ }^{\circledR}$ & $29.8 \pm 0.140$ & $6.62 \pm 0.807$ & 1.44 & 22.5 \\
\hline Ludipress $^{\circledR}+\mathrm{PDH}$ & $32.7 \pm 0.137$ & $4.84 \pm 0.065$ & 1.17 & 14.5 \\
\hline F-L12 & $34.1 \pm 0.260$ & $3.54 \pm 0.190$ & 1.13 & 11.4 \\
\hline
\end{tabular}

$*_{n}=3$ 
Higher CI values were obtained from microcrystalline cellulose based F-A formulation and agglomerated alfa-lactose monohydrate based F-T formulation (20.3\% and $16.2 \%$ respectively). These results and their HI values (1.25 and 1.19 respectively) pointed out that formulations prepared with Avicel ${ }^{\circledR}$ and Tablettose ${ }^{\circledR}$ ha fair flow character. Good flow properties with the lowest $\mathrm{HI}$ and CI values were obtained from the formulations prepared by combined type co-processed DTAs, StarLac ${ }^{\circledR}$ (F-S) and Ludipress ${ }^{\circledR}$ (F-L12) (11.3\% and $11.4 \%$ CI and 1.13 of HI, respectively) (Table 2). The decreasing values of $\mathrm{CI}$ and $\mathrm{HI}$ in the presence of magnesium stearate indicate that the interparticulate friction reduces and the particle rearrangement during the consolidation becomes easier.

\section{Determination of compressibility behaviour of powder mixtures}

The relationship between compact density and applied pressure during compression is the main approach to derive a mathematical representation of the compression. Thus, the most recognised expression in pharmaceutical science is Heckel equation. The reciprocal of the slope value represents the yield stress or yield pressure $(\mathrm{Py}=1 / \mathrm{K})$ for the particles. Py is defined as the stress at which plastic deformation of a particle is initiated $(1,8,22,23)$. Py value represents the compression characteristics of powder; the lesser the value of Py, the greater tendency towards plastic deformation. The parameters of Heckel equation are given in Table 3. The Heckel plots of formulations prepared with different DTAs are shown in Figure 1.

Table 3. Parameters calculated from Hechel equation for the tablet formulations prepared with different DTAs.

\begin{tabular}{lllll}
\hline Code of Formulation & $\mathbf{A}$ & $\mathbf{K}$ & $\mathbf{r}^{2}$ & $\mathbf{P y}$ \\
\hline F-A & 1.83 & 0.007 & 0.7210 & 125.0 \\
F-T & 1.31 & 0.008 & 0.9960 & 142.9 \\
F-S & 0.947 & 0.009 & 0.9910 & 90.91 \\
F-L12 & 1.39 & 0.011 & 0.8550 & 111.1 \\
\hline
\end{tabular}

The smaller Py values were calculated from F-S and F-L12. In general, a low Py value (higher slope) reflects low resistance to pressure, good densification, higher plastic deformation ability, and easy compression. The highest Py value of F-T might be caused by its moisture content impairing its compressibilty.

In the plot of F-L12, initial linear part means plastic deformation and the following plateau is explained by the work of hardening and change of crystal density and also indicates elastic deformation of the powder $(1,22-24)$. The plot 
of Avicel PH $102^{\circledR}$ based F-A formulation shows a prominent elastic deformation which is insensitive to the increasing pressure (Figure 1).

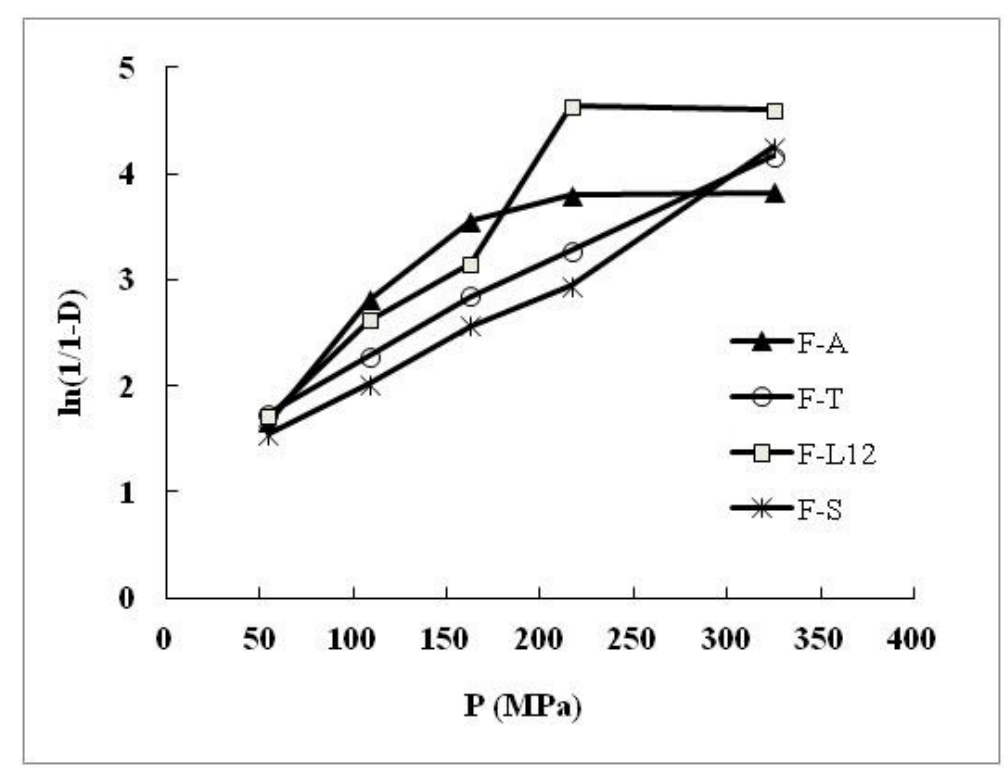

Figure 1. Heckel plots of formulations prepared with different DTAs.

Kawakita equation was developed to study powder compression using the degree of volume reduction $(1,23)$. The parameters calculated from Kawakita equation for the formulations prepared with different DTAs are given in Table 4. Constant $\boldsymbol{a}$ of this equation is equal to the minimum porosity of the bed prior to compression while $\boldsymbol{b}$ which is termed the coefficient compression, is related to the plasticity of the material and inversely related to the yield strength of the particles $(22,23,25)$.

Table 4. Parameters calculated from Kawakita equation of tablet formulations prepared with different DTAs

\begin{tabular}{lcccc}
\hline $\begin{array}{l}\text { Code of } \\
\text { Formulation }\end{array}$ & $\boldsymbol{a}$ & $\boldsymbol{b}$ & $\mathbf{1 / b}$ & $\mathbf{r}^{\mathbf{2}}$ \\
\hline F-A & 0.721 & 0.149 & 6.711 & 0.9999 \\
F-T & 0.493 & 0.256 & 3.906 & 0.9993 \\
F-S & 0.557 & 0.0427 & 23.41 & 0.9994 \\
F-L12 & 0.571 & 0.0972 & 10.28 & 0.9999 \\
\hline
\end{tabular}


The parameter $\boldsymbol{a}$ in the Kawakita equation indicates the degree of volume reduction of a powder mass (25). The highest $\boldsymbol{a}$ value which was observed for F-A formulation, indicated the highest porosity and volume reduction. This finding is consistent with the CI and HI values of the formulation. On the other hand, the value of $1 / b$ was decreased.

The higher values of $\mathbf{1 / b}$ have been reported to be related to the higher force required to reduce the volume to one half of the powders' original volume and resulted from the particle fragmentation during compression (26). Theoretically, volume reduction of spherical particles is difficult. Therefore, F-S formulation containing $\operatorname{StarLac}^{\circledR}$ in the form of spray-dried spherical particles required the highest force and gave the highest $1 / b$ value. Although this result seems contradictory to the Heckel Py values, it has been stated that Kawakita $1 / \mathrm{b}$ values is more effective to describe the compression behaviour of porous agglomerates. The results obtained from Kawakita equation can be ascribed to the individual particle properties of the DTAs.

\section{Evaluation of flow properties of the formulations prepared with the increasing amount of PDH}

Ludipress based formulations containing the increasing amount of PDH were evaluated to see the effects of drug on the flow properties and compressibility of the DTA. The angle of repose values were not affected significantly with the increasing amount of PDH from $12 \%$ to $36 \%$. Flow rates of the formulations decreased with the increasing amounts of the drug and $\mathrm{HI}$ and $\mathrm{CI}$ values became higher, accordingly. This result pointed out the poor compressibility of powder mixtures. However, the addition of magnesium stearate improved these properties and the optimum drug concentration was found to be $12 \%$ regarding powder flow properties $(15,17)$ (Table 5$)$.

Table 5. Flow properties and consolidation behaviour of Ludipress ${ }^{\circledR}$ with the different amounts of PDH

\begin{tabular}{|c|c|c|c|c|}
\hline Powder and Powder Mixture & $\begin{array}{l}\text { Angle of Repose } \\
\text { (degree) } \pm \mathrm{SE}^{*}\end{array}$ & $\begin{array}{l}\text { Flow Rate } \pm \mathrm{SE}^{*} \\
(\mathrm{~g} / \mathrm{sec})\end{array}$ & Hausner Index & $\begin{array}{l}\text { Carr's } \\
\text { Index (\%) }\end{array}$ \\
\hline Ludipress $^{(R)}$ & $29.8 \pm 0.171$ & $6.62 \pm 0.98$ & 1.44 & 22.5 \\
\hline Ludipress $^{\circledR}+12 \% \mathrm{PDH}$ & $32.7 \pm 0.167$ & $4.84 \pm 0.080$ & 1.17 & 14.5 \\
\hline F-L12 & $34.1 \pm 0.318$ & $3.54 \pm 0.233$ & 1.13 & 11.4 \\
\hline Ludipress $^{\circledR}+18 \% \mathrm{PDH}$ & $28.6 \pm 0.633$ & $5.51 \pm 0.531$ & 1.24 & 19.6 \\
\hline F-L18 & $30.4 \pm 0.465$ & $4.19 \pm 0.333$ & 1.18 & 15.3 \\
\hline Ludipress $^{\circledR}+24 \% \mathrm{PDH}$ & $27.9 \pm 1.39$ & $4.89 \pm 0.345$ & 1.24 & 19.1 \\
\hline F-L24 & $27.2 \pm 0.326$ & $3.90 \pm 0.174$ & 1.18 & 15.3 \\
\hline Ludipress $^{\circledR}+36 \% \mathrm{PDH}$ & $31.1 \pm 0.114$ & $3.49 \pm 0.461$ & 1.28 & 21.7 \\
\hline F-L36 & $30.8 \pm 0.227$ & $3.56 \pm 0.265$ & 1.19 & 16.6 \\
\hline
\end{tabular}

$* n=3$ 


\section{Determination of compressibility behaviour of the formulations prepared with the increasing amount of PDH}

Py values of the formulations prepared with different amounts of PDH are given in Table 6. The lowest Py value was obtained for F-L18. As seen in Figure 2, this formulation shows a different profile in the Heckel plot. The elastic deformation region which is represented by the plateau in the Heckel plot, was not observed for this formulation; the higher the pressure, the greater the densification or volume reduction. The primary mechanism for the compression of the formulation, F-L18, was the plastic deformation. It has been thought that the drug particles fill the spaces between DTA particles and act as an binder and thus, $18 \%$ of the drug would be the optimum amount considering the dilution potential of Ludipress ${ }^{\circledR}$.

Table 6. Data determined from Hechel Equation of tablet formulations Prepared with increased percent amount of $\mathrm{PDH}$

\begin{tabular}{lllll}
\hline $\begin{array}{l}\text { Code of } \\
\text { Formulation }\end{array}$ & $\mathbf{A}$ & $\mathbf{K}$ & $\mathbf{r}^{2}$ & $\mathbf{P y}$ \\
\hline F-L12 & 1.39 & 0.011 & 0.8550 & 111.1 \\
F-L18 & 0.537 & 0.015 & 0.9492 & 65.36 \\
F-L24 & 1.23 & 0.011 & 0.9857 & 88.49 \\
F-L36 & 1.54 & 0.010 & 0.9306 & 105.3 \\
\hline
\end{tabular}

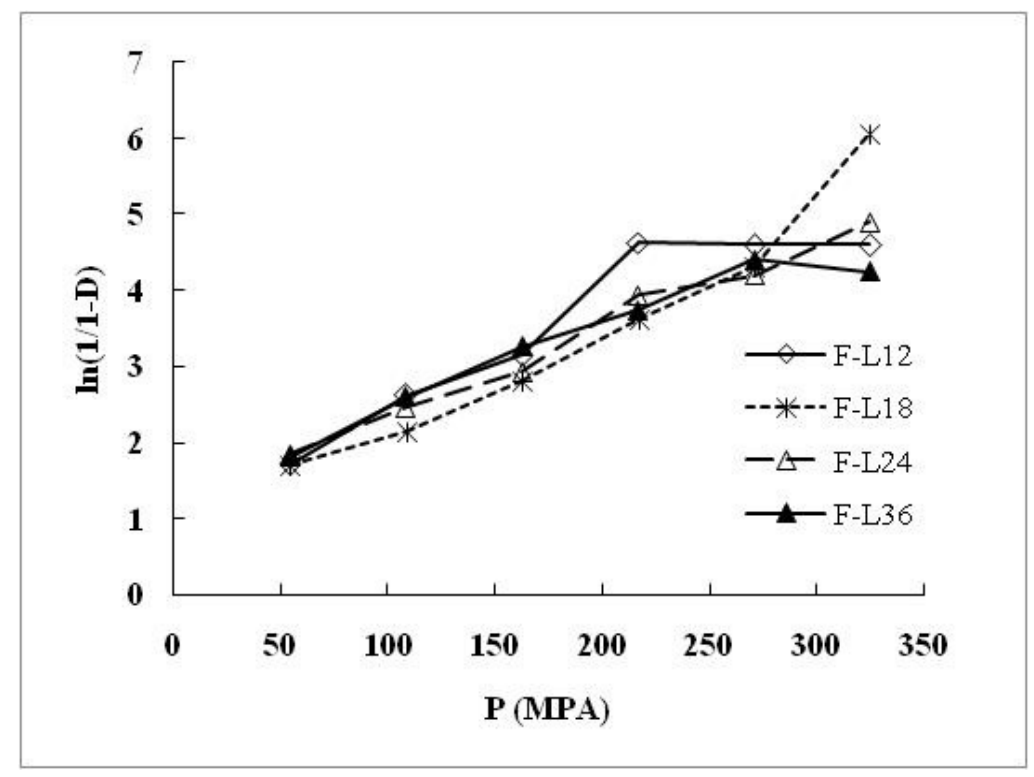

Figure 2. Heckel plot of formulations prepared with different percent amount of PDH. 
The $\boldsymbol{a}$ values of Kawakita equations obtained from the formulations containing different amounts of PDH, were not significantly different and revealed the lower interparticular porosity of the powder mass (Table 7). However, 1/b values were higher. For the F-L18 formulation, the highest $1 / b$ value indicated that the higher force required for the volume reduction.

Table 7. Data determined from Kawakita Equation of tablet formulation prepared with increased percent amount of PDH

\begin{tabular}{lcccc}
\hline $\begin{array}{l}\text { Code of } \\
\text { Formulation }\end{array}$ & $\boldsymbol{a}$ & $\boldsymbol{b}$ & $\mathbf{1} / \boldsymbol{b}$ & $\mathbf{r}^{\mathbf{2}}$ \\
\hline F-L12 & 0.571 & 0,0972 & 10.29 & 0,9999 \\
F-L18 & 0.569 & 0.0411 & 24.33 & 0.9992 \\
F-L24 & 0.552 & 0.0718 & 13.93 & 0.9993 \\
F-L36 & 0.544 & 0.0619 & 16.16 & 0.9993 \\
\hline
\end{tabular}

\section{CONCLUSION}

In this study, flow properties and compressibilities of different DTAs were evaluated by using PDH as a model drug. StarLac ${ }^{\circledR}$ and Ludipress ${ }^{\circledR}$ based formulations showed good flow properties as indicated by the lowest angle of repose and the highest flow rate. The Hausner and Carr's indexes of these agents were in the range of good flow characteristic values. The lowest Py values of powder mixture prepared with $\operatorname{StarLac}^{\circledR}$ or Ludipress ${ }^{\circledR}$ were also pointed out of acceptable compressibility. When Tablettose ${ }^{\circledR}$ was used in the formulation; the capping and lamination problems were occurred at the higher compression pressure. The plot of Avicel PH $102^{\circledR}$ based formulation obtained from Heckel equation showed a prominent elastic deformation. Optimum compressibility characters were obtained for the composition of $18 \%$ PDH and $82 \%$ Ludipress $^{\circledR}$ and also the lowest Py value and the highest determination coefficient of this formulation was represented the higher degree of plasticity.

Finally, the obtained results reveal that the co-processed DTAs are superior to the one component processed DTAs for flow properties and compressibility behaviors. However, the raw material, particle size and shape, and co-processing method of DTAs are also important factors which should be scrutinized. 


\section{REFERENCES}

1. Alderborn, G., "Tablets and Compaction", Aulton, M.E, (Ed.), Aulton's Pharmaceutics, The Design and Manufacture of Medicines, Churchill Livingstone Elsevier, Philadelphia, p. 41-482, (2007).

2. Patel, R.P., Bhavsar, M., "Directly Compressible Materials via Co-Processed", Int. J. Pharm. Tech. Research., 1(3), 745-753 (2009).

3. Yousuf, R.I., Shoarb, M.H., Ali, S.A., Haque, N., "Use of Avicel and Spray Dried Lactose in the Develeopment of levofloxacin 250mg Tablets By Direct Compression Method", Pakistan J. Pharmacol., 22 (2), 67-74, (2005).

4. Chougule, A.S., Dikpati, A., Trimbake, T., "Formulation Development Techniques of CoProcessed Excipients" J.f Adv. Pharm. Sci., 2 (2), 231-249 (2012).

5. Govedarica, B., Injac, R., Dreu, R., Srcic, S., "Formulation and Evaluation of Immidiate Release Tablets with Different Types of Paracetamol Powders Prepared by Direct Compression", African J. Pharm. Pharmacol., 5 (1), 31-41 (2011).

6. Gohel, M.C., "A Review of Co-Processed Directly Compressible Excipients", J.Pharm.Pharmaceut. Sci., 8(1), 76-93 (2005).

7. Dey, N.S., Panda, B.P., Rao, M.E.B., "Effect of Co-Processed Direct Compressible Vehicles on Fast Dissolving Tablets”, Int. J. Pharm. Tech. Res., 2(1), 771-783 (2010).

8. Patel, S.S., Patel, N.M., "Development of Directly Compressible Co-Processed Excipient For Dispersible Tablets Using $3^{2}$ Full Factorial Design”, Int. J. Pharm. and Pharmaceut. Sci., 1(1), 125-148 (2009).

9. Soppela, I., Airaksinen, S., Murtomaa, M., Tenho, M., Hatara, J., Raikkönen H., Yliruissi, J., Sandler, N., "Investigation of The Powder Flow Behaviour of Binary Mixtures of Microcrystalline Cellulose and Paracetamol”, J.Excipient Food Chem., 1 (1), 55-67 (2010).

10. Meggle Product overview of Tablettose, http://www.meggle-pharma.com/en/products-andservices/products/product-overview/tablettose-100-agglomerated-

11. Meggle Technical Brochure StarLac ${ }^{\circledR}$, Wasseburg, Germany. http://www.megglepharma.com/en/products-and-services/products/product-overview/starlac-coprocessed-

12. Basf Chemical Company Ludipress $^{\circledR}$ and Ludipress LCE Brochure. http://www.basf.com/group/corporate/en/brand/LUDIPRESS

13. Heinz, R., Wolf, H., Schuchmann, H., End. L., Kolter, K., "Formulation and Development of Tablets Based on Ludipress and Scale-Up from Laboratory to Production Scale”, Drug Dev. Ind. Pharm., 26 (5), 513-521 (2000).

14. Baykara, T., Duman, G., Özşener, K.Ş., Ordu, Ş., Özateş, B., "Comparing the Compressibilty of ludipress with the Other Direct Tableting Agents by Using Acetaminophen as an Active Ingradient”, Drug Dev. Ind. Pharm., 17 (17), 2359-2371 (1991). 
15. Staniforth, J.N., Aulton, M.E., "Powder Flow", Aulton, M.E., (Ed.), Aulton's Pharmaceutics, The Design and Manufacture of Medicines, Churchill Livingstone Elsevier, Philadelphia, p. 168-179 (2007).

16. Wadke, D.A., Serajuddin, A.T.M., Jacobsen, H., "Preformulation testing", Lieberman, Ha.A., Lachman, L., Schwartz, J.B.,(Eds), Pharmaceutical Dosage Forms-Tablets, Voll. $2^{\text {nd }}$ Ed. New York, p. 1-74 (1989).

17. European Pharmacopoeia 7.0, Council of Europe, Strasbourg, 305-311 (2011).

18. Shah, R.B., Tawakkul, M.A., Khan, M.A., "Comparative Evaluation of Flow for Pharmaceutical Powders and Granules", AAPS Pharm. Sci. Tech., 9(1), 250-258 (2008).

19. Villanova, J.C.O., Ayres, E., Orefice,R.L., "Design of Prolonged Release Tablets Using New Solid Acrylic Excipients for Direct Compression", Eur.J.Pharm.Biopharm. 79, 664-673 (2011).

20. Bacher, C., Olsen, P.M., Bertelsen, P., Sonnergaard, J.M., "Compressibility and Compactibilty of Granules Produced by Wet and Dry Granulation", Int. J. Pharm. 358, 6974 (2008).

21. Heckel, R.W., "Density-Pressure Relationships in Powder Compaction" Trans. Met. Soc. AIME, 221, 671-675 (1961).

22. Çomoğlu,T., “An Overwiew of Compaction Equations”, J. Fac. Pharm. Ankara, 36(2), 123133 (2007).

23. Odeku, O.A., "The Compaction of Pharmaceutical Powders", Pharmaceutical Information, Articles, Latests Reviews, 5(2) (2007), http://www.pharmainfo.net/reviews/compactionpharmaceutical-powders

24. Yüksel, N., Türkmen, B., Kurdoğlu, A.H., Başaran, B., Erkin, J., Baykara, T., "Lubricant Efficiency of Magnesium Stearate in Direct Compressible Powder Mixtures Comprising Cellactose ${ }^{\circledR} 80$ and Pyridoxine Hydrochloride”, J.Pharm.Sci., 32, 173-183 (2007).

25. Nicklasson, F., Alderborn, G., "Analysis of the Compression Mechanics of Pharmaceutical Agglomerates of Different Porosity and Composition Using the Adams and Kawakita Equations", Pharm. Res., 17 (8), 949-954 (2000).

26. Patel, S., Kaushal, A.M., Bansal, A.K., "Effect of Particle Size and Compression Force on Compaction Behavior and Derived Mathematical Parameters of Compressibility", Pharm. Res., 24 (1), 111-124 (2007). 